\title{
Knowledge, attitudes and perceptions regarding public-sector union responses to HIV/AIDS among Zimbabwe Teachers Association (ZIMTA) members
}

\author{
Kudakwashe Sithole ${ }^{1 *}$, Sekai Noreen Gore ${ }^{2}$, Kudzanayi Gondo ${ }^{3}$ \\ ${ }^{1-3}$ Zimbabwe Open University \\ Faculty of Commerce and Law Department of Management and Business Studies \\ Harare ZIMBABWE \\ *Email:sitholek@zou.ac.zw
}

\begin{abstract}
The role of trade unions in the fight against HIV/AIDS in the workplace is well documented. Although they have been slow and reactive, trade unions have started responding to the impacts of the epidemic. This paper describes knowledge, attitudes and perceptions regarding public-sector trade union responses to HIV/AIDS among Zimbabwe Teachers Association (ZIMTA) members. A mixed-method research design using three key informant interviews, 90 questionnaires and 3 focus group discussions were used to conduct this KAP analysis in Harare schools. The respondents were conveniently sampled. The findings revealed that levels of programme awareness and participation are very low. Although they appreciate the need for public-sector HIV/AIDS responses members are skeptical about the capacity of ZIMTA to implement comprehensive HIV/AIDS programmes for teachers. There is great need to scale-up interventions and ensure that they are owned by the memberships who are affected.
\end{abstract}

Key Words: knowledge, attitudes, perceptions, HIV, AIDS, teachers

\section{INTRODUCTION}

The education sector, like other sectors, is heavily affected by HIV and AIDS (Bennell, 2001). Although no detailed HIV risk assessment study of the teaching profession has been conducted in any African country, the impact of the epidemic in the education sector is well documented (Bennell, 2003). Teachers in Zambia and elsewhere in Southern Africa are dying at a rate faster than those being trained; within the next ten years, one teacher in every five is expected to die. In Africa, teachers report that an ever-increasing number of schoolchildren are orphans, and in Ethiopia alone, there are more than 1 million orphaned children. Teachers also note that an increasing number of their pupils stop attending school because they have to run a household and take care of their younger brothers and sisters.

Although it took teachers 15 years to realise that HIVand AIDS is more than a medical problem, all around the globe teachers' unions have adopted resolutions and policies on HIV and AIDS (UN, 2004). They have started disseminating information and have made training programmes part and parcel of their day-to-day work. Teachers' unions through Education International - the body representing 315 national affiliates and some 26 million employees from the education sector has been increasingly active in galvanizing teachers around the epidemic. In the United Republic of Tanzania, the Teachers Union decided that specific attention would be given to HIV and AIDS in all its meetings. Every issue of the monthly magazine of the South African Democratic Teachers Union features articles on HIV/AIDS and contributes to raise the awareness of the 210,000 Union members about the disease. Their work is based on the premise that with their presence in the workforce; unions are best placed to ensure that any plans and policies reach the workers they represent. Trade unions can reach a large proportion of the nation and therefore can educate their members as well as their families about the impact of HIV/AIDS. They can also negotiate for support and delivery of treatment and care. And importantly they can also lead the fight against stigma and discrimination of workers who are HIV positive. In Zimbabwe, Zimbabwe Teachers Association with its stakeholders namely; American Federation of Teachers (A FT), Education International (EI), Education Development Centre (EDC), and World Health Organisation, in 1999 initiated an intervention programme which includes teachers, learners and the wider community. The programme is a school based. Focal persons (Study Convenors) are trained using material generated by the Association. Such materials enable the teachers and learners to discuss issues related to HIV and AIDS in an atmosphere of colleagueship, and to find solutions to challenges facing teachers and learners in a particular setting. The first training of Master trainers was in January 2001.The group was made up of 120 participants from the 10 provinces. This was followed by the training of the first group of school based HIV/AIDS Study Circle Convenors in 2001.The initial training and retraining workshops were conducted in 2004, 2005 and 2006. 
Each of the 10 ZIMTA provinces selects at least 1 participant from their schools for training. The aim is to cascade the training to all members to learn how to use the ZIMTA /AFT kit and EI Exercise Books. To date, 2000 teachers have been trained.

Although there is data on what ZIMTA is doing, there is no data on how those programmes are received by their members. The objectives of the study were to answer the following questions:

- Do members have knowledge about HIV and AIDS programmes offered by their unions?

- What are members' attitudes and perceptions towards these programmes in the light of a slow and reactive approach by trade unions?

- What is it that members want to see unions doing to improve the pace and breadth of responses?

Understanding the levels knowledge, attitudes and perceptions regarding HIV and AIDS programmes in the workplace will enable a more efficient process of awareness creation as it will allow the programme to be tailored more appropriately to meet the needs of the members.

\section{METHODS}

A mixed research design using both quantitative research and qualitative research methods was used for this study. According to Creswell (2003), mixed research designs increases both the validity and reliability of data. Qualitative research was conducted to obtain in-depth data on HIV/AIDS programmes offered by ZIMTA and to gather in-depth data on membership perceptions regarding these programmes and quantitative research was conducted to gather data on knowledge and attitudes. The population for this study consisted of both secondary and primary school teachers in Zimbabwe employed by the Ministry of Education Sport and Culture of all age groups. 100 teachers from 10 randomly drawn schools in Harare Province were selected using convenient sampling methods. Teachers were approached during lunch time and permission was sought from all gatekeepers to take part in the study. Table 1 summarises the sample. Face-to Face key informant interviews were conducted with three ZIMTA officials responsible for HIV and AIDS and Training to collect data on union responses and how they are being received. They were also used to generate questions questionnaires. Extensive probing and open -ended questions characterized the interviews. Upon obtaining verbal consent from teachers, questionnaires were distributed. The questionnaire had three sections on knowledge, attitudes and perceptions. Questions on attitudes were rated on a 5 point Likert scale.

It was felt that interaction with respondents would stimulate new and valuable thought than questionnires.Group or peer pressure was valuable in challenging the thinking of respondents and illuminating conflicting opinions. Three focus group discussions with an average number of participants of seven were held. Data from FGDs was recorded in using detailed notes of what was said and how the discussions developed. Objectives of FGDs

i. $\quad$ Understand membership perceptions regarding union responses to HIV and AIDS.

ii. Make recommendations for developing adequate trade union responses to HIV and AIDS.

Data from questionnaires was analysed using Statistical Package for Social Sciences (SPSS) descriptive statistics. Key informant interviews and focus groups were analysed using Thematic Content Analysis.

\section{General Knowledge}

\section{RESULTS}

Sixty percent of the membership did not have knowledge about the programme whilst $39 \%$ (35) knew about it. Of those who knew about the programme $88 \%$ (79) had not been involved whilst $10 \%$ (9) had been involved as Facilitators of a Study Circle. None had been involved as Master trainers, Member of the Study Circle or Convenor. Seventy-six agreed that their schools have AIDS Action Clubs whilst $24 \%$ said they did not have.

\section{Attitudes and Perceptions}

All respondents (90) agreed that it was important for ZIMTA to be involved in HIV/AIDS activities for its membership.

\section{Encouraged positive living among membership}

Asked whether ZIMTA activities encouraged positive living among membership, 37 moderately agreed, 8\% strongly agreed, $11 \%$ were neutral, 17 moderately disagreed and $11 \%$ strongly disagreed.

\section{Increase in HIV Testing}

The majority (61\%) agreed that ZIMTA programmes encouraged members to undergo HIV testing. The figures are shown in table 4.

\section{Enabled membership to deal with Stigma and Discrimination}

The majority (40\%) moderately agreed that the programme has enabled teachers to deal with stigma and discrimination, $23 \%$ moderately disagreed $17 \%$ were neutral and $5 \%$ strongly agreed. 


\section{Programme adequacy and success}

Of those who were aware of the programme 53\% were of the view that the programme was a success whilst $34 \%$ sad it was not. Seventy-four percent were of the view that ZIMTA programmes were not adequate.

\section{Emerging themes}

The following themes emerged from the focus group discussions.

a. Trade Union Leaders need to lead by example

Participants echoed that before leaders can educate other workers about HIV/AIDS leaders need to be educated and demonstrate behaviour change and commitment.

b. Slow and Reactive

Participants were of the view that ZIMTA has been too slow to respond to HIV and AIDS among its membership. They noted that the impact of HIV and AIDS in schools was severe as noted by one participant who echoed:

"At my school we have lost 13 teachers since year 2000.Teachers need HIV and AIDS programmes as soon as yesterday"

They also agreed that HIV/AIDS programmes were very important in mitigating the impact of the epidemic.

c. The need market programmes and to reach out to more

Members felt that ZIMTA programmes were not known. In shock, one participant noted:

"ZIMTA has never been to our school. They should reach out in schools and introduce their programs to teachers."

d. Programmes are Important

Participants noted that ZIMTA programmes are important since they allow teachers to discuss issues related to HIV and AIDS. In one focus one participant who had attended the Study Circle echoed:

"I have learnt a lot of issues relating to HIV and AIDS including dealing with stigma and discrimination. To me it was an empowering experience"

One participant however objected:

"HIV and AIDS is not a trade union issue and ZIMTA should concentrate on collective bargaining to enhance membership standards of living."

e. Top-Down Approach will not achieve results

One participant echoed that

The problem with ZIMTA is that programmes have been thrown onto us. We need to own the programme.

f. Tackling Poverty Among Teachers is the getaway to HIV and AIDS prevention

The feeling among membership was that ZIMTA needs to do more in terms of negotiating for better working conditions for its membership. One participant noted that because teachers are living in absolute poverty, they have lost their dignity and this puts them at risk of HIV infection.

g. Facilitators should be able to deal with stigma and discrimination

In order for ZIMTA to effectively deal with HIV and AIDS there is need for Facilitators to deal with stigma and discrimination.

h. The need to create partnerships with NGOs and other stakeholders

In order to reach out more teachers and enhance their effectiveness, ZIMTA programmes need to create synergies with other stakeholders in HIV and AIDS programming including community based organisations.

i. The need to for women involvement

There is need to encourage women to participate in HIV and AIDS programmes. Due of stereotypes, gender barriers and inhibitions on sex and sexuality women cannot participate well in Study Circles.

\section{j. Not just about information dissemination}

Participants noted that instead of just concentrating on information dissemination and psychosocial support, ZIMTA needs to ensure comprehensive programming, including mobilizing resources for Anti-Retroviral Therapy for its membership. One participant noted:

"Teachers are dying because there is no treatment and ZIMTA could come up with a package for teachers who are HIV positive."

There is also need to train members not just in educating their peers but also to include peer counseling just in case someone approaches them after Study Circles or in cases were pre-test counseling and post test counseling is required. 
The following theme emerged from the key informant interviews held with ZIMTA Secretariat for HIV/AIDS Resistance and Denial

Some members do not want to discuss issues of sex and sexuality with ZIMTA facilitators

Inconsistency in responses

Some members have been forthcoming in discussing issues related to HIV and AIDS. The training Officer remarked that

"One of the members reveled status at workshop, others however do not want to see Convenors."

\section{DISCUSSION}

This study on knowledge, attitudes and perceptions regarding public sector trade union responses to HIV/AIDS provides important data on HIV/AIDS programming among trade unions. The level of HIV andAIDS programme awareness among ZIMTA membership is very low and reflects the slow and reactive approach of trade unions to HIV/AIDS. Members expressed reserved sentiments on the ability of trade unions to deal effectively with HIV/AIDS in the workplace and called for the scaling-up of trade union programmes.

ZIMTA has not done enough in terms of HIV/AIDS programming and this concurs with Mapolisa (2004)'s findings on South African trade unions. Lack of programme awareness may be because ZIMTA does not have the capacity to spread the programme to schools mainly due to financial and structural constraints. This in addition may have limited the programme to HIV/AIDS awareness and skills training among learners to avoid infection which require little resources. There is no significant difference in gender awareness of the programme among males and females. The majority of those who are aware that ZIMTA has HIV and AIDS programmes are not aware that they link members to psychosocial support for those who go for testing.

There are mixed feelings on the perceived of ZIMTA programmes on positive living, serostatus disclosure, HIV testing, dealing with stigma and discrimination and HIV and AIDS awareness. Members doubt the capability of ZIMTA's programmes to effectively deal with HIV/AIDS. This is mainly because there is no ownership by the membership of the programme since this is a donor project and some union members have no capacity to deal with HIV and AIDS.

This research although it was done in one province and has got limitations of generalisability of research findings, it provides important data on how public sector union responses to HIV/AIDS are received by their members. In conclusion, there is greater need for ZIMTA to scale up its programmes to ensure that they reach out more teachers and to ensure a comprehensive package in the fight against HIV/AIDS. With a bottomup approach, there will be ownership of the programmes and evidence has shown that where members own programme initiatives, the chances of success are very high.

Table 1: Demographic characteristics of respondents

\begin{tabular}{|l|l|l|}
\hline Variable & Frequency & Total \% \\
\hline Gender & & \\
\hline Male & 61 & 67.8 \\
\hline Female & 29 & 32.2 \\
\hline Age & & \\
\hline 30 years and younger & 36 & 53.3 \\
\hline $31-40$ & 46 & 40.1 \\
\hline $41-50$ & 8 & 5.6 \\
\hline Educational Qualification & & \\
\hline First degree/higher diploma or higher & 62 & 68.9 \\
\hline Diploma or Occupational certificate & 28 & 31.1 \\
\hline
\end{tabular}

Table 2: Programmes offered by ZIMTA

\begin{tabular}{|l|l|}
\hline Programme & \% Awareness \\
\hline HIV/AIDS Awareness & 71 \\
\hline $\begin{array}{l}\text { Psychosocial Support to members who test } \\
\text { positive }\end{array}$ & 20 \\
\hline $\begin{array}{l}\text { Material and Psychosocial Support to } \\
\text { Learners affected by the epidemic }\end{array}$ & 26 \\
\hline Skills building to learners to avoid risk & 70 \\
\hline
\end{tabular}


Table 3: Gender differences in Knowledge

\begin{tabular}{|llllll|}
\hline & Gender & Yes & & No & Total \\
& Male & 21 & 40 & $\mathbf{6 1}$ \\
& Female & 14 & 15 & $\mathbf{2 9}$ \\
Total & & $\mathbf{3 5}$ & $\mathbf{5 5}$ & $\mathbf{9 0}$ \\
\hline
\end{tabular}

Table 4: Programmes encourage HIV Testing

\begin{tabular}{|l|l|l|l|l|}
\hline $\begin{array}{l}\text { Strongly } \\
\text { Disagree }\end{array}$ & $\begin{array}{l}\text { Moderately } \\
\text { Disagree }\end{array}$ & Neutral & $\begin{array}{l}\text { Moderately } \\
\text { Agree }\end{array}$ & $\begin{array}{l}\text { Strongly } \\
\text { Agree }\end{array}$ \\
\hline 8 & 17 & 14 & 45 & 16 \\
\hline
\end{tabular}

\section{REFERENCES}

[1] AbT Associates. 2002. The impact of HIV/AIDS on the education sector in Zimbabwe, Mimeo, Johannesburg.

[2] Bennell, P.S. 2002 The Impact of the AIDS Epidemic on Teacher Mortality in Sub-Saharan Africa, Knowledge and Skills for Development, Brighton

[3] Bennell, P.S.(2001) The AIDS epidemic in Sub-Saharan Africa: Are teachers a high risk group?Bighton:Mimeo,May

[4] EFAIDS Brochure(n.d) The ZIMTA/AFT/EI/WHO/EDC HIV and AIDS Programme for Teachers and Learners

[5] Gregson S., H. Waddell, and S Chandiwanza. 2000. School education and HIV control in sub-Saharan Africa: from harmony to discord. Journal of International Development

[6] Mapolisa, S.(2004) South African Trade Union Responses to HIV/AIDS, International Conference on AIDS.2004 Jul 11-16:15,Centre for Health Policy, Johannesburg

[7] Wouter van der Schaaf, Global Partnerships in HIV/AIDS Education Influence Attitudes and Help Save Lives Worldwide Retrieved April, 28, 2008 from http://www.un.org/Pubs/chronicle/2004/issue1/0104p49.asp 